\title{
Rend mig i traditionerne
}

\section{Af Ib Marcussen og Troels V. Østergaard}

I GeologiskNyt nr. 2 fra dette årbragte vi to indlæg om jordartskortet - et kortere debatindlæg og et længere svar. Denne artikel er et svar på det lange indlæg fra nr. 2

I debatten om "det ærlige jordartskort" (Geologisk Nyt 2/06) fremfører Peter Gravesen og hans hold fra GEUS den "historiske arv" som begrundelse for, at smeltevandssand og grus vest for Ussings Linie benævnes "Ekstramarginale dannelser" på Jordartskortet, men ikke øst for den.

Vi kan henvise til en endnu ældre arv i den geologiske historie, nemlig til Abraham Gottlob Werner (1749 - 1817), der er blevet kaldt den moderne geologis fader (Adams, F.D.: The birth and development of geological sciences, Dover 1954), fordi han understregede betydningen af observationer, der ikke kunne diskuteres i modsætningen til tolkningerne af dem. I øvrigt er det et generelt princip i al empirisk videnskab, at observationer er én ting og tolkningen af dem en anden - som vi, der er gamle nok til at have haft filosofikum under studiet, har lært.

\section{Ren empiri}

Jordartskortet fremstår som ren empiri, og det er derfor videnskabsteoretisk uholdbart at blande en geomorfologisk tolkning ind $\mathrm{i}$ de data, det viser.

Peter Gravesen m. fl. giver to begrundelser for at gøre det, nemlig "kalkudvaskningen i de ekstramarginale dannelser" og "de geomorfologiske karakteristika". Sammen gør de, at der er "al mulig grund til, at der er skelnet mellem ekstramarginalt flodsand og glacialt smeltevandssand".

Vandet i de ektramarginale floder var måske ikke smeltevand? eller er der noget, vi har misforstået? Og det bliver værre endnu: I den klassiske tolkning er det meste af smeltevandssandet afsat foran isranden, altså ekstramarginalt. (Det er baggrunden for det "kinetostratigrafiske princip": først kommer isen og lægger et lag bundmoræne, så trækker den sig tilbage og lægger en hedeslette (smeltevandssand). Så kommer der en ny is, der gør det samme. Derfor kan man tælle isfremstød bare ved at tælle morænebænke - se fx Kjær et. al., Boreas

Karteringskort fra Tingbjerg Hedeslette (udsnit NV for Åbenrå). Kartøren har åbenbart ikke varet klar over, at han gik vest for Ussings Linie, siden han har fundet så meget smeltevandssand (rødt). (Kilde: Fra DGU serie A nr. 21978 p. 78: "Den geologiske kortlcegning af Danmark")

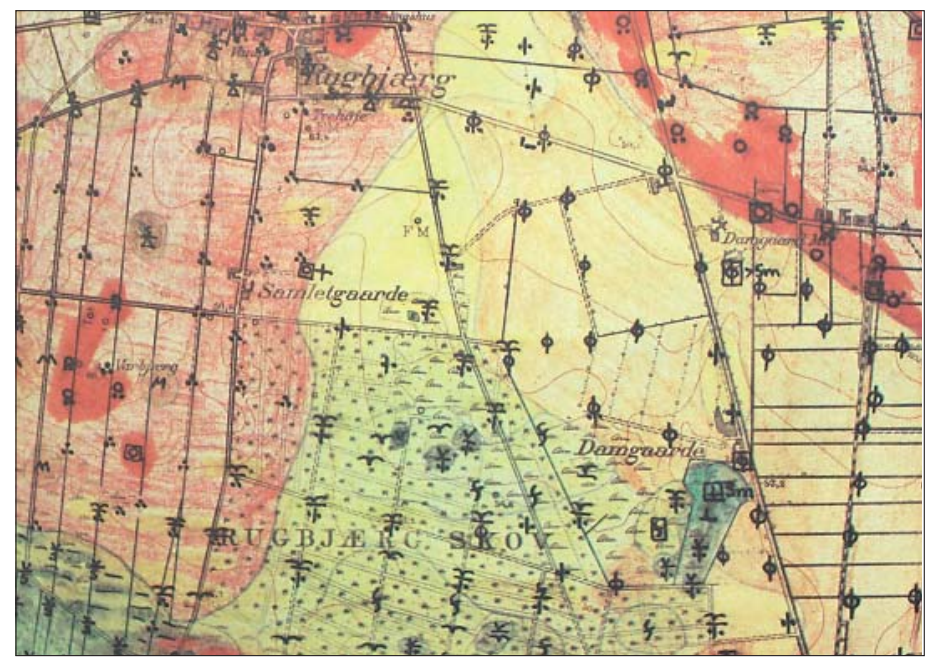

vol. 32, 2003 p. 135, der anser rækkefølgen af morænebænke i et profil for "uafhængig stratigrafisk information").

Man skelner altså i virkeligheden mellem ekstramarginalt smeltevandssand og ekstramarginalt smeltevandssand. Hvis kalkudvaskningen er vigtig i denne sammenhæng, kunne man have indført en betegnelse som "udvasket smeltevandssand" eller lignende. Det havde også været mere brugervenligt. I øvrigt ved man vel ikke, om der overhovedet har været kalk i sandet. De geomorfologiske karakteristika hører hjemme på et geomorfologisk kort, der jo helt klart er en tolkning af landskabets former.

Gravesen m.fl. skriver, at de glaciale aflejringer - det er dem, der i deres terminologi, bl.a. består af smeltevandssand - "alle på et tidspunkt under istiden [har] været dækket af en gletscher", og "fælles for alle de glaciale aflejringer er, at de har været belastet af vægten fra et isdække."

Påstanden om, at man på den smule materiale, karteringsspyddet henter op (og Jordartskortet er baseret på karteringer med spyd), kan skelne mellem isbelastet og ikkeisbelastet sand, må vist være opfundet til lejligheden. Vi vil i hvert fald meget gerne have en reference til en beskrivelse af metoden.

\section{Smeltevandssandet rejser flere spørgsmål} Pointen i den lille anekdote om Helge Gry var netop, at når man står derude i marken, kan man ikke se forskel på smeltevandssandet på de to sider af Ussings Linie. Gravesen m.fl. finder det både "utroværdigt og uværdigt", at inddrage Gry i denne diskussion. Det kan vi nu ikke se, for den viser Gry som en forsker, der ikke lå under for en misforstået loyalitet over for sin institution, og vi hæfter os ved, at Gravesen m.fl. ikke sætter spørgsmålstegn ved pointen i anekdoten.

Det isbelastede smeltevandssand rejser flere spørgsmål: Hvis smeltevandssandet ligger øverst - og det må det jo gøre for at komme med på jordartskortet - hvad er det så for en is, der har dækket det? Hvis den er forsvundet uden at efterlade sig spor, hvordan kan man så vide, at den har været der? Og hvis smeltevandssandet har været dækket af is, betyder det så, at modellen bag det kinetostratigrafiske princip ikke holder?

Naturligvis er det pindehuggeri, men man bør da kunne kræve, at der er en logisk konsistent tankegang bag det, der bliver til det officielle jordartskort. Og nu vi er ved det: Gravesen m.fl. tager issøaflejringer med blandt de aflejringer, der ikke har været isdækket. Alligevel har de den røde smeltevandssandsfarve, som vi ellers har lært er forbeholdt isbelastet sand.

Gravesen m.fl. er ikke de eneste, der henviser til traditionen. Også Houmark (Geologisk Tidsskrift 2003. 1) har bebrejdet os, at vi i vores forslag til en nytolkning af istidslandskabet (se "Danmarks Geologiske Seværdigheder" og www.geologiskesevaerdigheder.dk)) bryder med en hundredeårig tradition. Det er naturligvis aldrig populært blandt traditionalister, hvad fx Galilei - uden sammenligning i øvrigt - også måtte sande. 